УДК 94(560=35) «19»:304

DOI: $10.21779 / 2542-0313-2021-36-2-18-24$

\title{
Ш.Т. Абдуразакова
}

\section{Судьба дагестанской диаспоры в Турции, Сирии и Иордании в конце XX века}

Дагестанский государственный университет; Россия, 367000, г. Махачкала, ул. М. Гаджиева, 43a; shekerhanuт69@mail.ru

В статье на основе исследований известных кавказоведов рассматривается современное состояние дагестанских диаспор, сформировавшихся на протяжении почти полутора столетий. Северокавказские диаспоры начинали складываться ещё до начала освоения Российским государством причерноморских и северокавказских территорий. Это было естественным процессом и не имело массового характера. Но со второй половины XIX века переселение перестало быть добровольным и мигрантов стало гораздо больше. В результате сложных геополитических процессов и колониальной политики России процесс переселения охватил фактически все народы Северного Кавказа и Дагестана. Эмиграция представителей народов Дагестана на сегодняшний день является исследовательской проблемой. Достаточно слабо изучены данные о численности переселенцев и современной дагестанской диаспоре.

В научной литературе для обозначения переселенцев с Кавказа используют название мухаджир. Оказавшись на территории Османской империи, мухаджиры численностью 1,51,7 млн человек вынуждены были адаптироваться к новым условиям существования. Это было непросто.

Современные условия Российского государства дают возможность для равноправного и свободного развития любого этноса. Изучение истории диаспор позволит избежать повторения трагических событий прошлого.

В статье рассматриваются основные проблемы дагестанских диаспор, которые сегодня находятся в государствах, образовавшихся на территории бывшей Османской империи: в Турции, Сирии, Иордании, Ираке.

Исследование истории народов Северного Кавказа в целом и Дагестана в частности невозможно без изучения истории многочисленных диаспор в странах ближнего и дальнего зарубежья. В связи со сложными процессами глобального характера, происходящими в мире и в ближневосточном регионе, эта тема сегодня приобретает особую актуальность.

Ключевые слова: северокавказская диаспора, дагестанская диаспора, мухаджсирство, Османская империя, Турция, Сирия, Иордания, этническая ассимиляция, идентичность.

Волны эмиграции оказывали влияние на демографические и этнокультурные процессы в странах, которые образовались после распада Османской империи. Северокавказская эмиграция привела к возникновению диаспор в Сирии, Ираке, Турции, Иордании. Географическое расселение и численность прибывавших переселенцев зависели от объективных и субъективных причин.

Дагестанцы в основном селились в Турции (в Мушском, Сивасском, Карском, Токатском, Стамбульском, Измирском, Кайсерийском вилаетах), Ираке, Иордании, Сирии, Саудовской Аравии, Египте. Данных о переселении дагестанцев на Балканы не имеется. 
Ещё в XIX веке у переселенцев сохранялся традиционный кавказский жизненный уклад. Даже браки заключались только эндогамные. Переселенцы старались сберечь свои языки и самобытную культуру.

Вопрос о численности переселенцев, как отмечается многими исследователями, один из самых сложных. Перед началом Второй мировой войны на территории Сирии существовало 44 селения северокавказских переселенцев (4.039 семей). Эти данные результатов переписи приводит французская мандатная администрация. Согласно переписи в 13 селениях проживало абадзехское население, в 12 - бжедуги, в 2 - дагестанцы, в 7 - кабардинцы, в 5 - чеченцы, в 2 - осетины с карачаевцами.

В Большой Советской энциклопедии есть данные о выходцах с Северного Кавказа - карачаевцах, абхазах, осетинах, дагестанцах, адыгах и других этносах в количестве около 150 тысяч человек [2, с. 81]. Эта цифра сильно занижена и не даёт полной объективной картины. Также занижены цифры и в справочнике С.И. Брука [3, с. 292]: он утверждает, что было 235 тысяч представителей северокавказских народов.

По данным А.В. Кушкабиева, на территории Сирии проживало 240 дагестанских и 320 чеченских семей [4, с. 126]. По мнению А.М. Магомеддадаева, в 30-е годы XX века на территории Сирии проживало около 25 тысяч человек - выходцев с Северного Кавказа [6, с. 132].

В начале 20-х годов XX века северокавказские эмигранты на территории Османского государства создавали разные общественные и культурно-просветительские организации, выполнявшие функции объединения и сохранения национальной идентичности. Многие из них занимались благотворительностью, оказывая посильную помощь семьям, попавшим в сложное положение. На сегодняшний день в Сирии существует Черкесское благотворительное общество, созданное в 1948 году. Позже, уже с 1960 года, при этой организации стали издавать журнал «Новости культуры», разные брошюры и календари на арабском языке. К 1995 году насчитывалось пять тысяч членов Общества. Именно это Общество занимается различными проблемами представителей кавказской диаспоры.

По официальным данным, представленным Черкесским благотворительным обществом, число черкесов в Сирии составляло к 1990 году 70 тысяч человек. Кроме самих черкесов (адыгские племена) в современной Сирии проживают более 2.5 тысяч дагестанцев, свыше 2.5 тысяч карачаевцев и балкарцев, почти 3 тысячи чеченцев, свыше тысячи абхазцев, почти тысяча осетин.

По данным Б.Р. Алиева, дагестанцев в Сирии не менее 8 тысяч человек [1, с. 63]. Кроме этого есть данные Мухаммада-Нура Дагестани, который говорит о 500 семействах дагестанцев, живших там в конце XX в. [6, с. 133]. Если учесть и эти данные, к началу 2000-х годов в Сирии проживало около 80 тысяч выходцев с Северного Кавказа. Нет более точных данных и сегодня. Дагестанская диаспора в Сирии приблизительно из 180 семей проживает в последнее время в Дейрфуле, недалеко от города Хомса. Там живут даргинцы, кумыки, лезгины, аварцы, лакцы, черкесы и другие народы. В селении Джиссин живут в основном аварцы, курды, арабы. Есть выходцы с Кавказа и в Дамаске, но их там немного. Во время гражданской войны в Сирийской Республике многие уехали, и сейчас сложно определить, сколько дагестанцев там осталось. К тому же в Сирии северокавказские диаспоры сильно подвержены ассимиляции.

Один из известных исследователей северокавказского мухаджирства Фасих Бадерхан, сириец с дагестанскими корнями, изучает роль представителей Кавказа и Дагестана в общественной и политической жизни Сирийской Республики. 
Многие из них стали офицерами, депутатами парламента, музыкантами, певцами. Среди них можно назвать Закарию ад-Дагестани (офицер), Казима Дагестани (учёный, социолог, начальник канцелярии премьер-министра, а затем президента Сирии), Эльфат Эдельби (писательница) и многие другие.

В Ираке также сформировалась дагестанская диаспора. Определить ее численность довольно сложно. В 1936 году в справочнике 79 \% диаспоры считалось местным коренным населением. Для преуменьшения численности остальных национальных этносов не учитывались армяне, айсары, евреи, «черкесы». Возможно, не учитывали и переселенцев с Северного Кавказа. Самым известным дагестанцем в Ираке был сын Мухаммада Фаззил-паши (губернатор Мосула, маршал Османской империи) - Гази Дагестани. Он являлся генералом Генерального штаба армии Ирака. Последние годы проживал в Лондоне в политической эмиграции. Его сын - Тимур Дагестани был женат на сестре короля Иордании. В настоящее время Тимур служит в МИДе королевства Иордании.

Представители дагестанской диаспоры сыграли большую роль в общественнополитической, культурно-просветительской и экономической жизни Сирии, Иордании, Турции. Они внесли свой вклад в развитие агротехники, в возделывание сельскохозяйственных культур, в развитие новых ремесел. Также среди представителей кавказских народов были известные деятели культуры и богословы: например, Омер Зия Бинатлы - учёный-богослов из селения Миатлы, художник Халил Мусаев (Мусаясул), писатель Кадыржан Кафлы из селения Урма, Мизанджы Мурадбей - один из младотурков, выходец из селения Урахи и др.

Местное население арабских государств чаще всего всех выходцев из северокавказского региона именует «черкесами». Это не всегда правильно. Межэтнические браки внутри диаспор народов Северного Кавказа стали обычным делом, но они стараются не смешиваться с местным населением. Дагестанцы, чеченцы, осетины и другие народы переняли многое и ассимилировались с черкесами, что спасло эти народы от полной ассимиляции с населением Турции, Сирии, Иордании и других государств.

Менее подверженной ассимиляции оказалась дагестанская диаспора в Османской империи. Для этого были и объективные, и субъективные причины. Можно отметить основные факторы, которые способствовали сохранению дагестанских обычаев, традиций и языков в Турции. А.М. Магомеддадаев называет наиболее важные из них: «Во-первых, в Турции проживало дагестанцев во много раз больше, чем в Сирии. Вовторых, дагестанцы с момента переселения в Турцию до 60-х годов XX века в основном проживали в мононациональных поселениях. В Сирии же дагестанцы имели всего два поселения, одно из которых, как указывалось выше, большинству жителей пришлось оставить из-за засухи» [6, с. 138].

Как отмечают многие исследователи, во время правления Абдул-Хамида II северокавказские мухаджиры пытались изучать историю эмиграции. Одним из инициаторов этой работы был сын Шамиля - Газимухаммад. Но, узнав об этом, султан выступил против их исследований. Многие горцы служили в государственных учреждениях, вооружённых силах, полиции. Ещё при османском правлении мухаджиры были с властями близки. Частично сохранению ментальности горцев способствовало то, что их образ жизни и традиции отличались от местных. Общая религия способствовала сближению с местным населением.

Выходцы из Дагестана основали много селений в Турции: Армуткёй, Явукёй, Дагистание, Енигази и др. Многие выходцы из Дагестана разных национальностей знают кумыкский и аварский языки: это связано с тем, что кумыкский и турецкий язы- 
ки похожи, а аварцев было больше всего среди эмигрировавших дагестанцев. Но в современных условиях урбанизации и глобализации ассимиляция происходит быстрее.

Диаспора дагестанцев в Турции имеет два издательства, в которых выходят книги и журналы на турецком языке, расчитанные на широкую читательскую аудиторию. Журналы выпускаются в Стамбуле и Ялове. С 1977 года в Стамбуле существует организация «Фонд Шамиля», которая объединяет проживающих в Турции дагестанцев. Фонд Шамиля имеет тесные связи с организацией «Ватан», проводит различные мероприятия. Создателем и президентом фонда был внук имама Шамиля Саид.

Выше упоминалось, что в годы наиболее активной эмиграции было сложно определить размер диаспоры. Определить сегодня численность потомков эмигрантов тоже непросто. Местные власти статистику не ведут. В проводимых переписях мухаджиры считаются представителями турецкого этноса, так как они исповедуют ислам и знают турецкий язык.

Есть следующие данные по этому вопросу. В конце XIX века, если доверять официальным переписям, там было более 400 тыс. кавказцев. Но по данным 1925 года таковыми считали себя уже 250 тыс. человек. Такая большая разница, тем более с учётом естественного прироста, объясняется лишь тем, что согласно пантюркистской политике Ататюрка проводилась массовая «тюркизация» разных народов, проживающих в Турции. Если согласиться с данными переписи 1955 года, кавказцами считают себя 91 тыс. человек [9, с. 13].

Старожилы, проживающие в Турции, еще сохраняют этническую культуру, знают свой национальный язык. Всего выходцев с Кавказа около 80 тысяч, из которых 2/3 не знают языка. А.А. Магомедов в своём исследовании приводит данные о 500 тысячах дагестанцев, проживающих за пределами страны. Скорее всего, в их число входят и живущие на территории СНГ [5, с. 62].

Говоря о своей родине, горцы обычно имеют в виду Северный Кавказ в целом, а не отдельные его районы. Раньше, как и сейчас, многие кавказцы мечтали о возвращении. Благодаря тому, что исчез «железный занавес», в принципе можно беспрепятственно попасть в любую страну Ближнего Востока.

В период «перестройки», в конце 1980-х годов, связи с северокавказской общиной становятся более тесными. Во всех северокавказских республиках имеются отделения общества «Ватан». С их помощью в последние десятилетия устанавливаются культурные связи со всеми кавказскими диаспорами в Сирии, Иордании, Турции, Ираке.

Налажены регулярные поездки делегаций северокавказских общин в республики Северного Кавказа. Такие встречи помогают находить следы затерявшихся династий, способствуют сохранению традиций, языка и ментальности диаспор.

Общество «Ватан» организует встречи деятелей науки и культуры, поездки туристических групп. На турецком и арабском языках издаются многие произведения дагестанских авторов. Это помогает сохранить культуру дагестанских диаспор. В современных условиях многие общественные организации выполняют просветительские и благотворительные функции.

В 1980-е годы в учебных заведениях Дагестана был начат приём молодёжи из Иордании и Сирии, а в начале 1990-х - из Турции. В наши дни налажены тесные отношения между Дагестанским государственным университетом и университетами Турции, Египта и Ирана. В страны Ближнего Востока выезжают с гастролями творческие коллективы.

В 1992 году в Махачкале состоялся Первый Международный конгресс соотечественников Дагестана. В конгрессе принимали активное участие делегации Дагестана, 
республик Северного Кавказа, Баку, Москвы, Екатеринбурга, Тбилиси, благотворительных обществ Иордании, Ирана, Сирии, Саудовской Аравии, Турции, Великобритании. Конгресс подтвердил создание Всемирной ассоциации соотечественников Дагестана (ВАСД). В 1997 году была проведена международная конференция, посвящённая 200-летию имама Шамиля.

В Турции и других странах Ближнего Востока живут дагестанцы, у которых фамилия отражает этническую принадлежность - «Дагестанлы» («Дагестани»). Многие не знают, откуда родом, из каких селений Дагестана их предки. И всё-таки определённая часть переселенцев сохраняет обычаи, традиции, языки. Дагестанские диаспоры стремятся сохранить свою этническую самобытность, так как чувствуют себя частью своего Отечества.

Представители северокавказских диаспор по-разному смотрят на своё настоящее и будущее. Часть из них хочет вернуться на родину. Периодически возникают проблемы с репатриацией северокавказских народов. На протяжении почти полуторавекового периода горцы не раз предпринимали попытки вернуться на родную землю, но осуществить это мало кому удалось.

Репатриации мешает то, что желающие вернуться предъявляют определенные требования: получение двойного гражданства, предоставление льгот, признание депатриации народов и даже признание геноцида. Это очень сложные проблемы. Но прогнозировать дальнейшее развитие невозможно без объективного изучения истории и современного положения наших соотечественников за пределами Российского государства.

\section{Литература}

1. Алиев Б.Р. Из жизни не исчезнет след // Народы Дагестана. - 1993. - № 2. C. $61-63$.

2. БСЭ. - М.: Сов. энциклопедия, 1978. - Т. 29. - 592 с.

3. Брук С.И. Население мира. Этнодемографический справочник. - М.: Наука, 1986. -832 c.

4. Кушкабиев А.В. Черкесы в Сирии. - Нальчик: Респ. фонд «Возрождение», 1993. - $166 \mathrm{c}$.

5. Магомедов А.А. Дагестан и дагестанцы в мире (историко-политологический очерк). - Махачкала: Юпитер, 1994. - 312 с.

6. Магомеддадаев А.М. Эмиграция дагестанцев в Османскую империю (история и современность). - Махачкала: ДНЦ РАН, 2001. - 209 с.

7. Магомедханов М.М. Дагестанцы в Турции. - Махачкала: ДНЦ РАН, 1997. $134 \mathrm{c}$.

8. Магомедханов М.М. Дагестанская диаспора в Османской империи // Вестник Института ИАЭ ДНЦ РАН. - 2013. - № 2. - С. 127-138.

9. Современная Турция. - М.: Наука; Изд-во вост. лит., 1958. - 291 с.

10. Фасих Бадерхан. Северокавказская диаспора в Турции, Сирии и Иордании (вторая половина XIX - первая половина XX века). - М.: Институт востоковедения PAH, 2001. - $120 \mathrm{c}$. 


\title{
References
}

1. Aliyev B.R. The trace will not disappear from life // The people of Dagestan. 1993. - № 2. - P. 61-63.

2. TSB. T. 29. M.: Sov. encyclopedia, 1978. 592 p.

3. Brooke S.I. Population of the World. Ethnodemographic directory. M.: Science, 1986. $832 \mathrm{p}$.

4. Kushkabiyev A.V. Cherkes in Syria. Nalchik: Rep. Revival Foundation, 1993. $166 \mathrm{p}$.

5.Magomedov A.A. Dagestan and Dagestanians in the world. (historical and political essay). Makhachkala: Jupiter, 1994. 312 p.

6.Magomeddaev A.M. Emigration of Dagestanians to the Ottoman Empire. (History and modernity). Makhachkala: DNC RAS, 2001. 209 p.

7. Magomedkhanov M.M. Dagestanians in Turkey. Makhachkala: IIAE, 1997. 134 p.

8. Magomedkhanov M.M. Dagestan diaspora in the Ottoman Empire // Herald of the Institute of IAE. 2013. № 2. P. 127-138.

9. Modern Turkey. - Moscow: East. Lit., 1958. 291 p.

10. Fasih Baderhan. The North Caucasian diaspora in Turkey, Syria and Jordan (second half of the 19th - first half of the 20th century). M.: Institute of Oriental Studies of the Russian Academy of Sciences, 2001. 120 p.

Поступила в редакциию 3 декабря 2020 г.

UDC $94(560=35) \ll 19 »: 304$

DOI: $10.21779 / 2542-0313-2021-36-2-18-24$

\section{The Fate of the Dagestan Diaspora in Turkey, Syria, Jordan in the End of the XXth Century}

\section{Sh.T. Abdurazakova}

\begin{abstract}
Dagestan State University; Russia, 367000, Makhachkala, M. Gadzhiev st., 43a; shekerhanum69@mail.ru
\end{abstract}

On the basis of famous Caucasian scholars' studies s the modern state of the Dagestan diaspo$\mathrm{ra}$, formed over almost a century and a half is studied. The North Caucasian diaspora started developing even before the Russian state began to develop the Black Sea and North Caucasian territories. It was a natural process that was not practiced indiscriminately. But since the second half of the 19th century, the process of resettlement turned into a forced one leading to a greater number of migrants. As a result of Russia's complex geopolitical processes and colonial policies, the resettlement process has virtually covered all the peoples of the North Caucasus. The representatives of the peoples of Dagestan also found themselves in the whirlpool of these tragic events. In the scientific literature on this issue, the name "muhajir" is used to refer to immigrants from the Caucasus. Once in the Territory of the Ottoman Empire, the Muhajirs, according to various estimates numbering 1.5-1.7 million people, were forced to "get used" to the new conditions of existence. It was a difficult path, full of spiritual, nostalgic and physical suffering. The current conditions of the Russian state make equal and free de- 
velopment of any ethnic group possible. The history of events should help to avoid the recurrence of such tragedies.

Further, we tried to briefly address the main problems of the Dagestan diaspora, which are now located in the states formed in the territory of the former Ottoman Empire: Turkey, Syria, Jordan, Iraq. The history of the peoples of the North Caucasus and Dagestan, in particular, is impossible without studying the history of numerous diaspora in the countries of near and far abroad. In addition to the historical aspect, the relevance of this topic today is caused by complex global events taking place in the world and in the Middle East region.

Keywords: North Caucasian diaspora, Dagestan diaspora, Muhajir, Ottoman Empire, Turkey, Syria, Jordan, ethnic assimilation, identity.

Received 3 December 2020 